\title{
Pembuatan Sabun Padat Madu dengan Penambahan Ekstrak Kunyit (Curcuma domestica)
}

\author{
Making Honey Solid Soap with Addition of Turmeric (Curcuma domestica) Extract \\ FATIMAH $^{* 1}$, JAMILAH $^{1}$ \\ ${ }^{1}$ Jurusan Teknologi Industri Pertanian, Politeknik Negeri Tanah Laut, Jl. A. Yani, km.6, \\ Desa Panggung, Kec. Pelaihari. Kab. Tanah Laut, Kalimantan Selatan 70815, Indonesia \\ *Email: fatimah@politala.ac.id
}

\begin{abstract}
Bath soap is a compound of sodium or potassium with fatty acids, and contains oils and waxes, where the compound contains an unsaturated bond that will be easily oxidized, to maintain the quality of soap from oxidation reactions required antioxidants. The turmeric (Curcuma domestica) crop contain antioxidant and essential oil. This research aims are to know the characteristics of soap and to analyze the panelist response to the soap. This research to study about honey solid soap with addition of turmeric extract with different treatment there are $0 \mathrm{~g}, 2 \mathrm{~g}, 4 \mathrm{~g}$ and $6 \mathrm{~g}$. The tested of honey solid soap there are water content test, $\mathrm{pH}$ test, foam stability test, irritation test and organoleptic test. The results showed that the lowest water content was $11.49 \%$ and the highest was $15.54 \%$, soap $\mathrm{pH}$ ranged from 9.5-10, foam stability $84.15-89.27 \%$ and did not cause irritation skin. Panelist response to color, smell, texture and appearance of honey soap product with addition difference concentration of Curcuma domestica extract were not significantly different.
\end{abstract}

Keywords: Soap, Turmeric extract, Honey.

\begin{abstract}
ABSTRAK
Sabun mandi adalah senyawa natrium atau kalium dengan asam lemak, serta mengandung minyak dan lilin, dimana senyawa itu mengandung ikatan tidak jenuh yang akan mudah teroksidasi, untuk menjaga kualitas sabun dari reaksi oksidasi diperlukan bahan antioksidan. Kunyit (Curcuma domestica) merupakan tanaman yang mengandung antioksidan dan minyak atsiri. Penelitan ini bertujuan untuk mengetahui karakteristik sabun yang dihasilkan dan menganalisis respon panelis terhadap sabun yang dihasilkan. Penelitian ini untuk mengkaji sabun padat madu dengan penambahan ekstrak kunyit yang berbeda yaitu $0 \mathrm{~g}, 2 \mathrm{~g}, 4 \mathrm{~g}$ dan $6 \mathrm{~g}$. Uji sabun padat madu ini antara lain uji kadar air, uji $\mathrm{pH}$, uji stabilitas busa, uji iritasi dan uji organoleptik. Hasil penelitian menunjukkan kadar air terendah sebesar 11,49\% dan tertinggi sebesar 15,54\%, $\mathrm{pH}$ sabun berkisar antara 9,510, stabilitas busa sebesar 84,15-89,27\% dan tidak menyebabkan iritasi terhadap kulit. Respon panelis terhadap warna, aroma, tekstur dan penampakan produk sabun padat madu dengan penambahan ekstrak kunyit dengan konsentrasi yang berbeda adalah berbeda tidak nyata.
\end{abstract}

Kata kunci: Sabun, Ekstrak kunyit, Madu. 


\section{PENDAHULUAN}

Sabun mandi adalah senyawa natrium atau kalium dengan asam lemak dari minyak nabati dan atau lemak hewani berbentuk padat, lunak atau cair, berbusa digunakan sebagai pembersih, dengan menambahkan zat pewangi, dan bahan lainnya yang tidak membahayakan kesehatan (SNI 06-3532-1994). Sabun tersusun dari asam lemak, minyak dan lilin, dimana senyawa itu mengandung ikatan tidak jenuh yang akan mudah teroksidasi. Reaksi tersebut ditandai dengan keluarnya bau tengik pada sabun, untuk menjaga kualitas sabun dari reaksi oksidasi diperlukan bahan antioksidan.

Salah satu jenis tumbuhan yang mengandung antioksidan dan banyak digunakan oleh masyarakat sebagai obat trandisional adalah kunyit (Curcuma domestica), yang berasal dari keluarga jahe (Zingiberaceae family). Kunyit memiliki kandungan Curcumin yang tinggi. Senyawa kurkuminoid dalam ekstrak kunyit memiliki efek antioksidan yang berguna untuk tubuh dari radikal bebas, mencerahkan kulit, dan mengobati gatal-gatal pada kulit. Pangemanan, dkk (2016) menggunakan ekstrak kunyit untuk menghambat pertumbuhan bakteri Staphylococcus aureus dan Pseudomonas sp. Rini, dkk., (2018) melaporkan bahwa ekstrak kunyit mampu menghambat pertumbuhan bakteri Esherichia coli dan Bacillus subtilis.

Madu merupakan suatu larutan manis yang mengandung gula dan kental. Penambahan madu pada sabun diharapkan dapat meningkatkan nilai guna dari sabun, seperti memberikan kesan lembut, halus, melembabkan dan memberikan aktivitas antibakteri pada kulit. Sabun madu merupakan salah satu produk yang dapat digunakan sebagai salah satu inovasi dari penggunaan madu dalam industri kosmetik. Fatimah, dkk., (2016) menggunakan madu sebagai tambahan pada pembuatan sabun mandi, Qisti (2009) juga menggunakan madu pada pembuatan sabun transparan dan menghasilkan kadar air lebih tinggi dibandingkan dengan SNI 06-3532-1994, serta jumlah asam lemak yang lebih rendah, sedangkan penelitian penambahan ekstrak kunyit pada sabun padat madu belum dilaporkan.

\section{METODE PENELITIAN}

\section{Bahan}

Bahan yang diguanakan dalam penelitian ini adalah kunyit, madu, minyak kelapa, asam stearat, $\mathrm{NaOH}$, aquadest, etanol, gula, gliserin, asam sitrat dan $\mathrm{NaCl}$. 
Alat

Alat yang digunakan dalam penelitian ini adalah gelas beker, spatula, neraca analitik, cawan petri, kertas $\mathrm{pH}$, thermometer, cetakan sabun, hotplate, sendok, saringan, blender, masker dan sarung tangan.

\section{Pembuatan Sabun Padat Madu dengan Penambahan Ekstrak Kunyit}

Tahap pertama yang dilakukan adalah dengan menyiapkan $100 \mathrm{~g}$ ekstrak kunyit yang mana mula-mula dikupas bersih kunyit, kemudian diparut agar mendapatkan kunyit yang halus. Selanjutnya parutan kunyit ditambahkan air sebanyak $100 \mathrm{~g}$ kemudian disaring untuk mendapatkan ekstraknya, kemudian ekstrak kunyit ditimbang berdasarkan perlakuan SK0 (tanpa ekstrak kunyit), SK1 (2 g ekstrak kunyit), SK2 (4 g ekstrak kunyit), dan SK3 (6 g ekstrak kunyit).

Kemudian tahap kedua mula-mula ditimbang madu sebanyak 1,8 g. Selanjutnya larutkan $\mathrm{NaOH}$ sebanyak 3,5 g dalam $15 \mathrm{~g}$ aquadest untuk perlakuan SK0, $13 \mathrm{~g}$ aquadest untuk perlakuan SK2, $11 \mathrm{~g}$ aquadest untuk perlakuan SK3, dan $9 \mathrm{~g}$ aquadest untuk perlakuan SK4. Selanjutnya masukkan madu dan ekstrak kunyit yang telah ditimbang sesuai perlakuan, aduk hingga homogen. Pencampuran bahan-bahan tersebut akan mengakibatkan larutan menjadi panas, oleh karena itu tunggu larutan mendingin hingga suhu $50^{\circ} \mathrm{C}$, cek suhu larutan tersebut menggunakan termometer. Kemudian untuk campuran lainnya yaitu timbang minyak kelapa sebanyak $25 \mathrm{~g}$ dan asam stearat sebanyak 10 g. Campur kedua bahan minyak tersebut hingga homogen pada suhu $70^{\circ} \mathrm{C}$. Selanjutnya tambahkan larutan $\mathrm{NaOH}$ ke dalam campuran minyak tersebut sedikit demi sedikit. Kemudian tambahkan bahan-bahan pendukung seperti 3,5 g etanol, 1,5 g gula, 3 $\mathrm{g}$ gliserin, $1 \mathrm{~g}$ asam sitrat, dan $1 \mathrm{~g} \mathrm{NaCl}$. Homogenkan bahan dengan cara mengaduknya hingga tercampur rata. Setelah adonan tercampur rata, cetak menggunakan pencetak dan diamkan selama 1 minggu. Kemudian lakukan analisis uji terhadap sabun yang dihasilkan.

\section{Uji Kadar Air}

Adapun cara untuk menguji kadar air pada sabun kunyit dengan penambahan madu ini adalah dengan memasukkan cawan ke dalam lemari pengeringan selama 1 jam. Kemudian keluarkan cawan dan masukkan dalam desikator agar suhu cawan normal kembali, lalu timbang berat kosong cawan dan catat beratnya. Selanjutnya masukkan $5 \mathrm{~g}$ 
sampel dalam cawan lalu masukkan dalam oven selama 2 jam dengan suhu $105^{\circ} \mathrm{C}$. Setelah 2 jam keluarkan dan timbang cawan beserta sampel tersebut (Sari, dkk., 2010).

$$
\text { Kadar air }(\%)=\frac{\text { Berat sampel awal }- \text { Berat sampel akhir }}{\text { Berat sampel awal }} \times 100 \%
$$

\section{Uji pH Sabun}

Adapun cara untuk menguji derajat keasaman sabun yaitu dengan menyiapkan 5 g sampel yang akan dianalisis pH-nya. Sampel dilarutkan ke dalam $10 \mathrm{ml}$ aquadest. pH diukur dengan memasukkan $\mathrm{pH}$ meter yang telah dicuci dengan aquadest. Angka yang tertera pada $\mathrm{pH}$ meter dicatat sebagai $\mathrm{pH}$ sabun (Sari dkk, 2010).

\section{Uji Stabilitas Busa}

Sabun sebanyak $1 \mathrm{~g}$ dimasukkan ke tabung reaksi yang berisi $10 \mathrm{ml}$ aquadest, kemudian dikocok selama 1 menit. Busa yang terbentuk diukur tingginya menggunakan penggaris (tinggi busa awal). Tinggi busa diukur kembali setelah 5 menit (tinggi busa akhir) (Jannah, 2009). Kemudian stabilitas busa dihitung dengan rumus :

Uji stabilitas busa $=100 \%-(\%$ busa yang hilang $)$

$$
\% \text { busa yang hilang }=\frac{\text { (Tinggi busa awal }- \text { tinggi busa akhir) }}{\text { Tinggi busa awal }} \times 100 \%
$$

\section{Uji Iritasi}

Iritasi pemakaian sabun dilakukan terhadap 10 orang panelis dengan cara membasahi tangan panelis dengan air, kemudian diberikan sabun yang akan diuji. Sabun yang diaplikasikan ke tangan kemudian digosok-gosok selama satu menit. Tangan dicuci, kemudian didiamkan selama lima menit. Iritasi diamati dengan jalan melihat terjadinya perubahan pada kulit seperti kemerahan, gatal dan kasar (Ayu dkk, 2009).

\section{Analisis Respon Panelis}

Analisis respon panelis ini bertujuan untuk mengetahui kesukaan panelis menggunakan uji organoleptik terhadap sabun yang dibuat berdasarkan tekstur, penampakan (warna dan bentuk sabun), pembusaan, wangi, kesan lembut dan kesan kesat dari sabun (Maripa, dkk., 2014). Adapun untuk menguji organoleptik dari sabun padat madu dengan penambahan ekstrak kunyit terhadap 10 panelis. Pada uji ini sampel 
disajikan kepada panelis untuk memberikan penilaian pada warna, aroma, tekstur dan penampakan dengan cara mengamati sampel kemudian mengisi lembar uji yang telah disediakan.

\section{HASIL DAN PEMBAHASAN}

\section{Sabun Padat Madu dengan Penambahan Ekstrak Kunyit}

Sabun terbentuk dari reaksi antara basa $\mathrm{NaOH}$ dan minyak maupun asam lemak berupa asam stearat. Pada pembuatan sabun padat madu dengan penambahan ekstrak kunyit yang memiliki konsentrasi kunyit yang berbeda-beda yaitu SK0 (tanpa ekstrak kunyit), SK1 (2 g ekstrak kunyit), SK2 (4 g ekstrak kunyit), SK3 (6 g ekstrak kunyit) menghasilkan sabun yang dapat dilihat pada Gambar sebagai berikut.

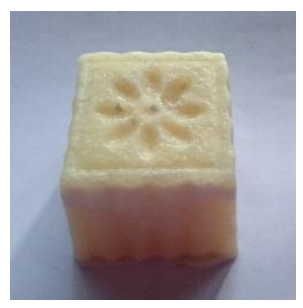

(a)

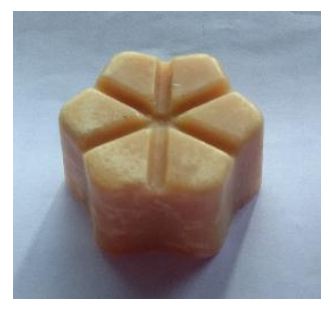

(b)

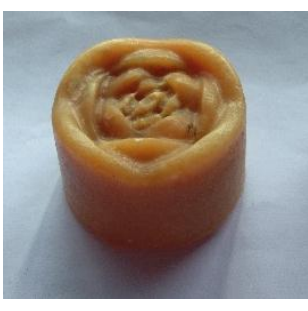

(c)

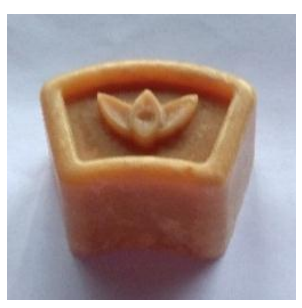

(d)

Gambar 1. Sabun padat madu dengan penambahan ekstrak kunyit

(a) SK0, (b) SK1, (c) SK2 dan (d) SK3

\section{Karakteristik Sabun Padat Madu dengan Penambahan Ekstrak Kunyit}

Hasil uji karakteristik pada sabun padat madu dengan penambahan ekstrak kunyit dapat dilihat pada Tabel 1.

Tabel 1. Data karakteristik sabun padat madu dengan penambahan ekstrak kunyit

\begin{tabular}{cccc}
\hline Perlakuan & $\begin{array}{c}\text { Rata-rata Kadar } \\
\text { Air }(\boldsymbol{\%})\end{array}$ & pH & $\begin{array}{c}\text { Rata-rata Stabilitas } \\
\text { Busa (\%) }\end{array}$ \\
\hline SK0 & 14,54 & 10 & 84,15 \\
SK1 & 12,82 & 10 & 83,14 \\
SK2 & 12,01 & 10 & 86,41 \\
SK3 & 11,49 & 9,5 & 89,27 \\
\hline Keterangan : & SK0 = Sabun tanpa penambahan ekstrak kunyit \\
& SK1 = Sabun dengan penambahan ekstrak kunyit sebanyak 2 g \\
& SK2 = Sabun dengan penambahan ekstrak kunyit sebanyak 4 g \\
& SK3 = Sabun dengan penambahan ekstrak kunyit sebanyak 6 g
\end{tabular}




\section{Uji Kadar Air}

Berdasarkan SNI 06-3532-1994, kadar air dalam sediaan sabun padat maksimal 15\%. Berdasarkan hasil uji kadar air (Tabel 1) bahwa semua perlakuan memiliki kadar yang telah memenuhi SNI 06-3532-1994, yaitu kurang dari 15\%. Sabun yang telah didiamkan selama 1 minggu menjadi keras. Sukawaty, dkk. (2013) melaporkan bahwa sabun yang terbuat dari ekstrak etanol bawang tiwai pada awalnya lunak dan berubah menjadi keras setelah 2 minggu sehingga kadar air memenuhi SNI 06-3532-1994. Menurut Sameng (2013), kadar air sabun sari beras telah memenuhi SNI 06-3532-1994. Pada penyimpanan, air dengan kadar tersebut akan menunjukkan daya simpan lebih baik. Kadar air sabun akan sangat mempengaruhi kekerasan sabun padat madu yang dihasilkan. Kadar air tertinggi dihasilkan oleh perlakuan tanpa penambahan ekstrak kunyit dengan nilai rata-rata $14,54 \%$, sedangkan kadar air terendah dihasilkan oleh perlakuan dengan penambahan 6 g ekstrak kunyit dengan rata-rata kadar air 11,49\%. Kadar air terendah tersebut dikarenakan pada penambahan $6 \mathrm{~g}$ ekstrak kunyit ini hanya $9 \mathrm{~g}$ aquadest yang dimasukkan untuk mengkonstankan jumlah pelarut yang terdiri dari aquadest dan ekstrak kunyit yaitu sebanyak $15 \mathrm{~g}$. Sedangkan pada perlakuan tanpa penambahan ekstrak kunyit, hanya terdiri atas pelarut aquadest sebanyak $15 \mathrm{~g}$.

\section{Uji pH}

Nilai pH sabun padat madu dengan penambahan ekstrak kunyit memiliki pH berkisar antara 9,5 sampai 10 . Sabun yang baik memiliki $\mathrm{pH}$ yang tidak menyebabkan iritasi bagi kulit dan tidak menjadikan kulit kering. Berdasarkan hasil uji organoleptik, sabun ekstrak kunyit yang dihasilkan pada berbagai perlakuan tidak menyebabkan iritasi kulit. Nilai pH sabun yang dihasilkan menunjukkan bahwa sabun bersifat basa. Jumlah alkali yang berasal dari $\mathrm{NaOH}$ akan menjadikan sabun bersifat basa dan mempengaruhi besarnya nilai $\mathrm{pH}$. Sasongko dan Mumpuni (2017) melaporkan bahwa pH sabun yang terbuat dari ekstrak pegagan memiliki $\mathrm{pH}$ pada rentang yaitu 9,7 - 9,9, sabun yang terbuat dari lengkuas memiliki pH 10,09-10,63 (Hernani, dkk., 2010). Wijayanti, dkk., 2016 menyatakan bahwa ekstrak kunyit memiliki pH sebesar 6,4 dan kadar asam sebesar $0,37 \%$. Banyaknya penambahan ekstrak kunyit dapat menurunkan nilai pH basa sabun. pH sabun yang mengandung ekstrak kunyit lebih rendah dibandingkan $\mathrm{pH}$ sabun tanpa ekstrak kunyit, sehingga pada penambahan ekstrak kunyit sebanyak $6 \mathrm{~g}$ dapat menurunkan $\mathrm{pH}$ menjadi 9,5. 


\section{Uji Stabilitas Busa}

Stabilitas busa dinyatakan sebagai ketahanan suatu gelembung untuk mempertahankan ukuran dan atau pecahnya lapisan film dari gelembung. Badan Standarisasi Nasional (BSN) belum membuat standar fisik sabun. Tidak ada persyaratan tinggi busa minimum atau maksimum untuk suatu sediaan sabun, karena tinggi busa tidak menunjukkan kemampuan dalam membersihkan. Hal ini lebih terkait pada persepsi psikologis dan estetika yang disukai oleh konsumen (Vairappan, 2003 dalam Rahayu, 2015). Rata-rata nilai stabilitas busa untuk semua perlakuan berkisar antara $83,14 \%$ sampai $89,27 \%$. Sameng (2013) melaporkan bahwa sabun dari sari beras sebesar 69\% $69,75 \%$. Hasil sabun dari ekstrak kunyit memiliki stabilitas busa yang tinggi dan menjadi parameter bahwa sudah terjadi reaksi penyabunan dan terbentuk sabun.

\section{Uji Iritasi}

Kandungan, karakteristik dan penggunaan sabun mandi yang kurang baik dapat menyebabkan reaksi berupa iritasi pada kulit, oleh karena itu dilakukan uji iritasi untuk mengetahui ada atau tidaknya reaksi berupa iritasi tersebut terhadap kulit. Berikut data hasil uji iritasi pada kulit dapat dilihat pada Tabel 2.

Tabel 2. Data uji iritasi terhadap kulit panelis

\begin{tabular}{cccc}
\hline \multirow{2}{*}{ Perlakuan } & \multicolumn{3}{c}{ Parameter Uji } \\
\cline { 2 - 4 } & KKolit Kemerahan & Kulit Gatal & Kulit kasar \\
SK1 & - & - & - \\
SK2 & - & - & - \\
SK3 & - & - & - \\
\hline Keterangan : & SK0 = Sabun tanpa penambahan ekstrak kunyit \\
& SK1 = Sabun dengan penambahan ekstrak kunyit sebanyak 2 g \\
& SK2 = Sabun dengan penambahan ekstrak kunyit sebanyak 4 g & \\
& SK3 = Sabun dengan penambahan ekstrak kunyit sebanyak 6 g & \\
Keterangan tanda : & \\
&
\end{tabular}

Tabel di atas menunjukkan bahwa perlakuan dengan penambahan ekstrak kunyit yang berbeda pada sabun padat madu tidak menyebabkan iritasi pada kulit panelis. Iritasi pada kulit dapat disebabkan oleh pH sabun yang terlalu tinggi atau terlalu rendah. Selain itu, kunyit memiliki kandungan senyawa antibakteri yang telah mampu menghambat pertumbuhan bakteri (Rini, dkk., 2018 dan Pangemanan, dkk., 2016), khasiat kunyit lainnya dapat mengobati gatal-gatal (Kinho, dkk., 2011). Kandungan senyawa anti 
bakteri pada kunyit memungkinkan mampu mengurangi terjadinya iritasi pada kulit, sehingga sabun padat madu dengan penambahan ekstrak kunyit ini aman untuk digunakan.

\section{Analisis Respon Panelis}

Uji organoleptik terhadap sabun padat madu dengan penambahan ekstrak kunyit terdapat beberapa pengamatan yaitu warna, aroma, tekstur dan penampakan dengan 5 skala penetapan yaitu sangat suka, suka, cukup suka, kurang suka dan tidak suka. Hasil uji organoleptik tersebut dapat dilihat pada Tabel 3 sebagai berikut.

Tabel 3. Data uji organoleptik sabun padat madu dengan penambahan ekstrak kunyit

\begin{tabular}{|c|c|c|c|c|}
\hline \multirow{2}{*}{ Sampel } & \multicolumn{4}{|c|}{ Pengamatan } \\
\hline & Warna & Aroma & Tekstur & Penampakan \\
\hline SK0 & 3.8 & 3.5 & 4 & 3.9 \\
\hline SK1 & 3.6 & 3.5 & 4 & 3.7 \\
\hline SK2 & 3.2 & 3.7 & 3.8 & 3.5 \\
\hline SK3 & 3.6 & 3.6 & 4.1 & 3.8 \\
\hline Keterangan : & \multicolumn{4}{|c|}{$\begin{array}{l}\text { SK0 }=\text { Sabun tanpa penambahan ekstrak kunyit } \\
\text { SK1 }=\text { Sabun dengan penambahan ekstrak kunyit sebanyak } 2 \mathrm{~g} \\
\text { SK2 }=\text { Sabun dengan penambahan ekstrak kunyit sebanyak } 4 \mathrm{~g} \\
\text { SK3 }=\text { Sabun dengan penambahan ekstrak kunyit sebanyak } 6 \mathrm{~g}\end{array}$} \\
\hline \multicolumn{5}{|c|}{$\begin{array}{l}\text { Keterangan Angka: } \\
5=\text { Sangat suka } \\
4=\text { suka } \\
3=\text { Cukup suka } \\
2=\text { Kurang suka } \\
1=\text { Tidak suka }\end{array}$} \\
\hline
\end{tabular}

Berdasarkan hasil dari 4 perlakuan, penerimaan panelis terhadap sabun padat madu dengan penambahan ekstrak kunyit untuk warna adalah pada perlakuan tanpa ekstrak kunyit dengan nilai 3,8, untuk aroma adalah perlakuan dengan penambahan $4 \mathrm{~g}$ ekstrak kunyit, kemudian untuk tekstur adalah pada perlakuan dengan penambahan $6 \mathrm{~g}$ ekstrak kunyit, sedangkan untuk penampakan adalah pada perlakuan tanpa ekstrak kunyit.

Warna sabun padat madu dengan penambahan ekstrak kunyit yang dihasilkan berwarna coklat kekuningan dan semakin tinggi konsentrasi yang ditambahkan warna sabun akan semakin menjadi coklat kekuningan, hal ini karena ekstrak kunyit mengandung senyawa kurkumin. Kurkumin dapat menguraikan ikatan-ikatan pada basa menjadi ikatan kompleks, sehingga ketika basa bereaksi dengan ekstrak kunyit akan mengalami perubahan warna menjadi merah kecoklatan (Ginting, 2016). Kemudian untuk aroma kunyit tidak terlalu tercium, dikarenakan aroma minyak kelapa lebih dominan dibanding aroma kunyit, serta konsentrasi yang ditambahkan tidak banyak. 
Kemudian dilanjutkan dengan Uji ANOVA yang mana bertujuan untuk mengetahui pengaruh perlakuan berdasarkan hasil uji organoleptik, meliputi warna, aroma, tekstur dan penampakan dapat dilihat pada Tabel 4 sebagai berikut.

Tabel 4. Uji ANOVA pengaruh ekstrak kunyit terhadap sabun padat madu

\begin{tabular}{lccc}
\hline \multicolumn{1}{c}{ Pengamatan } & F hitung & F tabel 1\% & F tabel 5\% \\
\hline Warna & $2.28^{\mathrm{tn}}$ & 4.37 & 2.87 \\
Aroma & $0.25^{\mathrm{tn}}$ & 4.37 & 2.87 \\
Tekstur & $0.46^{\mathrm{tn}}$ & 4.37 & 2.87 \\
Penampakan & $1.15^{\mathrm{tn}}$ & 4.37 & 2.87 \\
\hline Keterangan : & & & \\
tn = Berpengaruh tidak nyata & & &
\end{tabular}

Data yang didapat dari uji organoleptik menggunakan uji ANOVA single factor untuk warna, aroma, tekstur dan penampakan dapat diketahui bahwa pengaruh perbedaan rata-rata dari beberapa perlakuan ekstrak kunyit yang ditambahkan yaitu berpengaruh tidak nyata ( $\mathrm{F}$ hitung $<\mathrm{F}$ tabel $1 \%$ ). Hal ini menunjukkan bahwa panelis memberikan penilaian yang sama terhadap parameter kesukaan tersebut, sehingga 4 perlakuan penambahan ekstrak kunyit baik tanpa ekstrak kunyit, 2 g ekstrak kunyit, 4 g ekstrak kunyit maupun $6 \mathrm{~g}$ ekstrak kunyit yang berbeda terhadap sabun padat madu yang dihasilkan tidak berbeda nyata.

\section{KESIMPULAN}

Berdasarkan hasil penelitian pembuatan sabun padat madu dengan penambahan ekstrak kunyit memiliki kadar air yang telah memenuhi SNI yaitu dibawah 15\%. pH sabun berkisar 9,5-10, tidak menyebabkan iritasi pada kulit dan memiliki nilai stabilitas busa sebesar $83,14 \%-89,27 \%$.

\section{UCAPAN TERIMA KASIH}

Terimakasih kepada Program Studi Teknologi Industri Pertanian Politeknik Negeri Tanah Laut yang telah mendukung terlaksananya kegiatan penelitian.

\section{DAFTAR PUSTAKA}

Ayu D. F., Ali A., dan Sulaiman R. (2009). Evaluasi Mutu Sabun Padat dari Minyak Goreng Bekas Makanan Jajanan di Kecamatan Tampan Kota Pekanbaru dengan 
Penambahan Natrium Hidroksida dan Lama Waktu Penyabunan. Laporan Penelitian Hibah Bersaing. Universitas Riau, Pekanbaru.

Dewan Standardisasi Nasional. 1994. Standar Mutu Sabun Mandi Padat. SNI 06-35321994. Departemen Perindustrian Nasional, Jakarta.

Fatimah, Sandri D., Nuryati. (2016). Pembuatan sabun Madu Bagi Masyarakat Petani Lebah Madu. Jurnal Pengabdian kepada Masyarakat Vol. 1 No. 1.

Ginting, J.P.S. (2016). Strip Tes Berbasis Kurkumin untuk Deteksi Boraks pada Sampel Makanan. (Skripsi). Universitas Jember. Jember.

Hernani, Bunasor TK, dan Fitriani (2010) 'Formula Sabun Transparan Antijamur Dengan Bahan’, Bul. Littro. Vol. 21 No. 2, 2010, 192 - 205

Jannah, B. (2009). Sifat Fisik Sabun Transparan dengan Penambahan Madu pada Konsentrasi yang Berbeda. (Skripsi). Departemen Ilmu Produksi dan Teknologi Peternakan, Fakultas Peternakan, Institut Pertanian Bogor.

Kinho J., Arini, DID., Tabba, S., Kama, H., Kafiar, Y., Shabri, S., dan Karundeng, MC. (2011). Tumbuhan Obat Tradisional Di Sulawesi Utara Jilid 1. Balai Penelitian Kehutanan Manado.

Maripa B. R., Kurniasih Y., dan Ahmadi. (2014). Pengaruh Konsentrasi NaOH terhadap Kualitas Sabun Padat dari Minyak Kelapa (Cocos Nucifera) yang Ditambahkan Sari Bunga Mawar (Rosa L.). Pendidikan Kimia, FPMIPA IKIP Mataram.

Pangemanan, Fatimawali, dan Budiarso. (2016). Uji daya hambat ekstrak rimpang kunyit (Curcuma longa) terhadap pertumbuhan bakteri Staphylococcus aureus dan Pseudomonas sp. Jurnal e-Biomedik (eBm), Volume 4, Nomor 1.

Qisti, R. (2009). Sifat Kimia Sabun Transparan dengan Penambahan Madu Pada Konsentrasi yang Berbeda. Skripsi. Departemen Ilmu Produksi dan Teknologi Peternakan. Fakultas Peternakan. Institut Pertanian Bogor.

Rahayu, S., (2015). Formulasi dan Evaluasi Mutu Fisik Sabun dari Ekstrak Rumput Laut Merah (Euchema cottoni). Jurnal Wiyata. Vol. 2 No. 1

Rini, CS., Rohmah, J., dan Widyaningrum, LY. (2018). Efektivitas Kunyit (Curcuma longa Linn) terhadap Esherichia coli dan Bacillus subtilis. Medicra (Journal of Medical Laboratory Science/Technology), 1 (1), Juni, 1-6. E. ISSN. 2580-7730.

Sameng, W. (2013). Formulasi Sediaan Sabun Padat Sari Beras (Oryza sativa) sebagai Antibakteri terhadap Staphylococcus epidermidis. Universitas Muhammadiyah Surakarta. Surakarta.

Sari T. I., Julianti P. K., dan Tri J. N. S. (2010). Pembuatan Sabun Padat dan Sabun Cair dari Minyak Jarak. Jurnal Teknik Kimia, No. 1, Vol. 17. 
Sasongko, H. and Mumpuni, A. S. (2017) 'Pengaruh penambahan sukrosa terhadap mutu sabun transparan dari ekstrak etanol herba pegagan (Centella asiatica L.)', Pharmaciana, 7(1), p. 71. doi: 10.12928/pharmaciana.v7i1.5795.

Sukawaty, Y., Warnida, H., dan Artha AV., (2016). Formulasi sediaan sabun mandi padat ekstrak etanol umbi bawang tiwai (Eleutherine bulbosa (mill.) Urb.). Media Farmasi Vol. 13 No.: 14-22

Wijayanti, R. K., Rukmi, W. D., dan Nugrahini. (2016). Pengaruh Proporsi Kunyit (Curcuma longa L.) dan Asam Jawa (Tamarindus indica) Terhadap Karakteristik Leather Kunyit Asam. Jurnal Pangan dan Agroindustri Vol. 4 No 1, 158-169. 